Journal of Science and Technology, Vol. 32, No. 1 (2012), pp 22-31 22

(C) 2012 Kwame Nkrumah University of Science and Technology (KNUST)

http://dx.doi.org/10.4314/just.v32i1.4

RESEARCH PAPER

\title{
ASSESSMENT OF WATER QUALITY PARAMETERS OF KPESHI LAGOON OF GHANA
}

\author{
J. Apau ${ }^{1}$, S. K. Appiah ${ }^{2}$, M. Marmon-Halm ${ }^{1}$ \\ ${ }^{1}$ Department of Chemistry, College of Science, KNUST, Kumasi, Ghana \\ apaujoseph@yahoo.com \\ ${ }^{2}$ Department of Mathematics, College of Science, KNUST, Kumasi, Ghana
}

\begin{abstract}
:
A study was carried out on the Kpeshi Lagoon to identify the chemical and physical characteristics of the water. A lot of industrial activities are carried out around the Lagoon and it is being gradually turned into a place of refuse damp. Standard methods were used for determining of chemical and physical characteristics of water samples. Trace metal ions were determined by atomic absorption spectrometry. The lagoon recorded mean $\mathrm{pH}$ and conductivity values of $6.32 \pm$ 2.20 and $87.31 \mathrm{~ms} / \mathrm{cm} \pm 19.14$ respectively. Nutrient and organic matter were found to be the most frequent cause of pollution of the lagoon with mean sulphate, nitrate and phosphate concentrations of $11852 \mathrm{mg} / \mathrm{l} \pm 2915.08,2905.71 \mathrm{mg} / \mathrm{l} \pm 616.52$ and $487.14 \mathrm{mg} / \mathrm{l} \pm 257.02$ respectively. Iron $(\mathrm{Fe})$ and aluminum $(\mathrm{Al})$ recorded the highest concentration of $13.2 \mathrm{mg} / \mathrm{l} \pm 3.47$ and $13.6 \mathrm{mg} / \mathrm{l} \pm$ 4.29 respectively in water sample. Fish sample revealed calcium and potassium as having the highest concentration of $15709 \mathrm{mg} / \mathrm{kg} \pm 75.35$ and $5999.94 \mathrm{mg} / \mathrm{kg} \pm 87.30$ respectively with sodium and aluminum recording $3775.70 \mathrm{mg} / \mathrm{kg} \pm 24.80$ and $708.47 \mathrm{mg} / \mathrm{kg} \pm 4.95$ respectively. The results as compared to the WHO guidelines indicate that the Lagoon is highly contaminated.
\end{abstract}

Keywords: Kpeshi lagoon, nutrients, trace metals.

\section{INTRODUCTION}

Lagoons are shallow coastal bodies of water separated from the ocean by a series of barrier islands which lie parallel to the shoreline. Inlets, either natural or man-made, cut through barrier islands and permit tidal currents to transport water into and out of the lagoons. Because lagoons are characteristically shallow, they are strongly influenced by precipitation and evaporation, which results in fluctuating water temperature and salinity. Lagoons can also be fragile ecosystems susceptible to pollution effects from municipal, industrial and agricultural runoff.

Lagoons are classified into 3 main types: leaky lagoons, choked lagoons, and restricted lagoons. Leaky lagoons have wide tidal channels, fast currents and unimpaired exchange of water with the ocean. Choked lagoons occur along high energy coastlines and have one or more long narrow channels which restrict water exchange with the ocean. Circulation within this type of lagoon is dominated by wind pat- 
terns. Restricted lagoons have multiple channels, well defined exchange with the ocean, and tend to show a net seaward transport of water. Wind patterns in restricted lagoons can also cause surface currents to develop, thus helping to transport large volumes of water downwind (Kjerfve 1986).

Lagoons are very important water bodies providing habitat for a wide range of flora and fauna. It provides a source of plant generic materials for research work (Ansah-Asare, et al.,1998). Lagoons and the vegetations that occur in them also improve evaporation and transpiration and thereby help stabilise the climate of the areas around them. Vegetation such as mangrove and forested wetlands also serve as wind-breaks and help to dissipate the force and impact of coastal storm surges (Dugan, 1990).

In Ghana, coastal wetlands are also centres for economic activities as they provide the environment for salt wining, fishing and vegetable growing.

Existing literature reveals that urbanization, high population growth, fuel wood gathering, salt and sand wining are among the major factors threatening mangrove and wetland ecosystems along the coast of Ghana. Some of these sites have come under the pressure of excessive human activity mainly estate development and uncontrolled ground water exploitation in the basins. (Ansah-Asare et al., 2001).

The Kpeshie lagoon, located $11 \mathrm{~km}$ East of Accra was originally fed by the sea making the area hydrographic. As a result of increase in population and urbanization, portions of the lagoon have been reclaimed and developed for residential purposes. The aim of this work is to find out the extent to which the activities carried out around the lagoon has impacted on its physico-chemical parameters. The main aim is to determine the physical and chemical parameters as well as some trace metals from the lagoon.

\section{METHODOLOGY}

\section{Study area}

The Kpeshi Lagoon lies on latitude 5.566 with latitude dimension of $5^{\circ} 34^{\prime} 0 \mathrm{~N}$ and longitude 0.133 with longitudinal dimension of $0^{\circ}-8^{\prime} 0 \mathrm{E}$ (Fig. 1). The lagoon is characteristically located on a low lying plain i.e. between Whitller Baracks corridor, on the eastern side and the La -Trade Fair corridor to the west where it forms a marshy zone. Due to on-going road and bridge construction activities, the lagoon seems to be divided into two with a portion on the other side of the bridge joining the sea occasionally. There is another portion of the water body isolated along the La-Palm-Zenith College road. The wetland covers an area of 22 $\mathrm{km}^{2}$ and comprises sand dune, open lagoon, marshy lands and scrublands. Due to recent developments, the wetland could be categorised into four sections. The first and second sections extend from La Trade-Fair centre to La-Palm Royal Hotel whereas the third section stretches from Teshie town. The fourth segment extends from Zenith College-Exopa lane. All four sections have various inlets into the lagoon. Unfortunately, the third and fourth sections are currently drying up due to pollution. The first and second have had their own fair share of the pollution but on a small scale compared to the former. Over the years, various educational and entertainment facilities as well as a gas filling station and a washing bay have been constructed around the vicinity. The more prominent constructions include Zenith College, LaPalm Royal Hotel, and Exopa Fashions. Fig. 2 are plates which shows portions of the Kpeshi Lagoon which has been turned to refuse dump through human activities.

A brief survey of the area was done and sampling points selected based on accessibility. Table 1 describes the sampling spots selected.

\section{Hydrometeorology and Hydrological condi- tion}

Meteorological data from the Kotoka International Airport, Accra was used for the study. Due to its proximity to the lagoon, the data was 




Fig.1: Map of Accra East showing the study area (Kpeshi Lagoon)

not expected to vary much although minor local variations are usually anticipated.

The study area lies in a semi-arid coastal savannah zone with mean annual rainfall of about $800 \mathrm{~mm}$ occurring in two rainy seasons. The first season accounts for about $65 \%$ of total rainfall and it usually begins in March and ends in late July while the second begins in midAugust and ends in October. Temperature variation is minimal throughout the year with a mean monthly temperature ranging between 24 ${ }^{\circ} \mathrm{C}$ in August and $28.1{ }^{\circ} \mathrm{C}$ in March.

Pan evaporation data from Accra indicates high evaporation rates occurring between MarchApril and also October-November with an estimated annual value of $1400 \mathrm{~mm}$. Relative humidity is generally high varying from $65 \%$ in the afternoon and up to $95 \%$ at night.

\section{Glass Ware}

High density 1.51 plastic containers were pretreated by washing with acetone to get rid of organic substances such as grease and fat res- dues. They were then washed with detergent and rinsed with deionised water before they were soaked in $0.1 \mathrm{M}$ nitric acid solution for 48 hours. The containers were rinsed with deionised water and made ready for use.

\section{Sampling Mode}

Water samples were collected from the sampling sites using cleaned high density 1.51 plastic bottles. At the sampling points, the bottles were lowered into the lagoon at a depth of about $30 \mathrm{~cm}$ below the water surface. Water samples for dissolved oxygen analysis were collected separately into $300 \mathrm{ml}$ plastic BOD bottles. The dissolved oxygen was fixed on the spot by adding $2 \mathrm{ml}$ each of $\mathrm{MnSO}_{4}$ and alkaliazide-iodide solution. Samples for Biochemical Oxygen Demand (BOD) were collected into other $300 \mathrm{ml}$ plastic bottles for subsequent incubation. Samples were stored on ice pack in coolers and transported to the laboratory.

\section{Experiments}

Standard methods prescribed in American Public Health Association (APHA, 1998) and Env- 

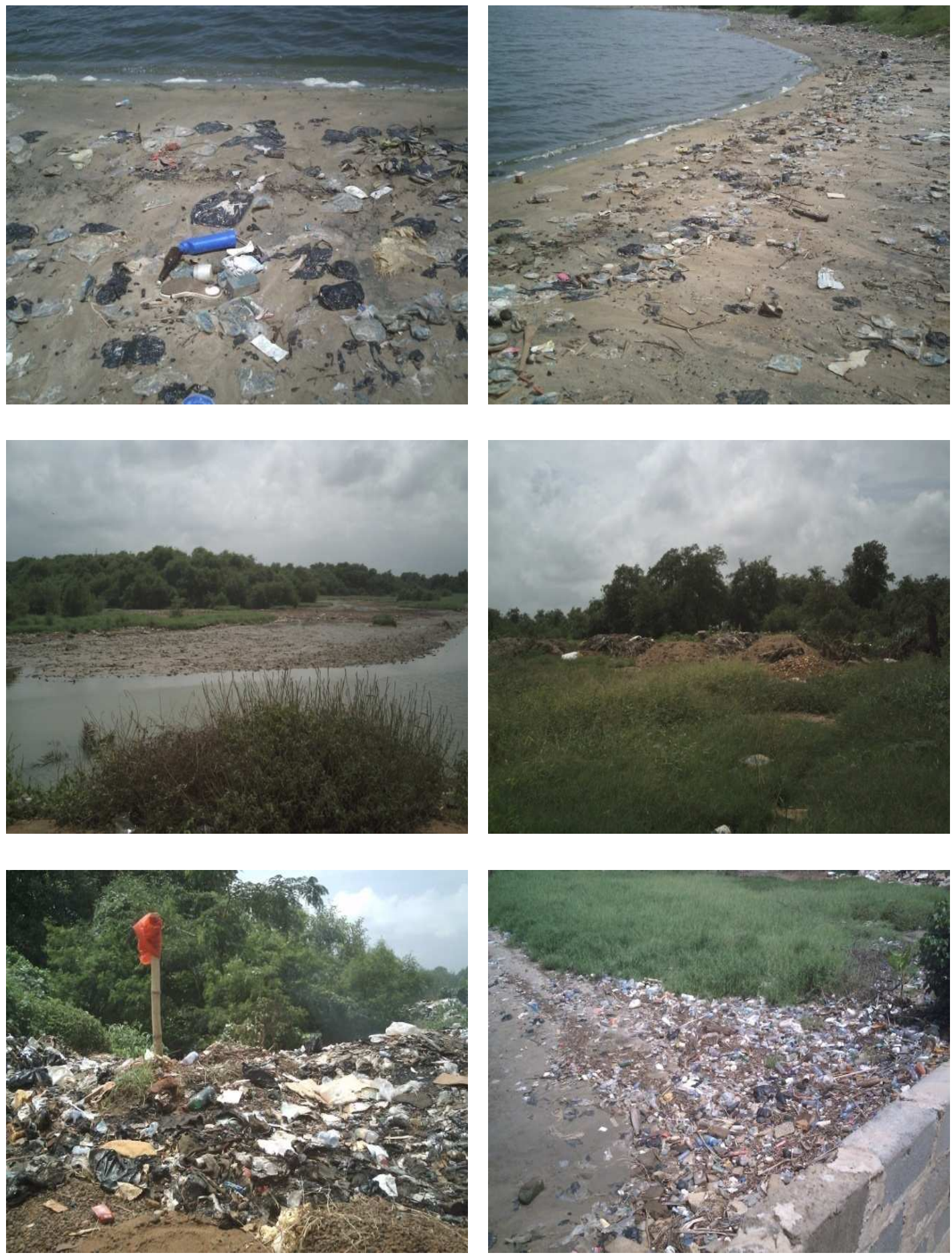

Fig. 2: Plates showing various sections along the lagoon

Journal of Science and Technology @ KNUST April 2012 
Table 1: Description of sampling points

\begin{tabular}{ll}
\hline Sampling point code & Location \\
\hline S1 & Up stream site 1 before bridge from Accra \\
S2 & Up stream site 2 outlet from Labadi Hotel \\
S3 & Up stream site 3 before bridge from Teshie \\
S4 & Down stream 4 before bridge from Teshie \\
S5 & Down stream 5 gas station outlet \\
S6 & Down stream 6 outlet from Exopa Burg \\
S7 & Down stream 7 opposite La-Palm Hotel \\
\hline
\end{tabular}

ironmental Protection Agency (EPA, 1983) were used to analyse water samples at the Chemistry Laboratories of the Ghana Atomic Energy Commission. All analyses were done in triplicates to ascertain reproducibility and quality assurance. The $\mathrm{pH}$, temperature, conductivity and total dissolved solids (TDS) were determined on site. Portable Hach $\mathrm{pH}$ meter calibrated with buffers 4,10 , and 12 was used for the $\mathrm{pH}$ readings. Calibrated Portable Hach Sension 5 conductivity meter was used to measure the temperature, conductivity and total dissolved solids in the water. Alkalinity and total hardness were determined by titrimetric method and chloride was determined by the Mohr Argentometric method. Sulphate, phosphate and nitrate were determined by colorimetric method using colorimeter (HACH DR/890). Flame emission photometric method was used to determine sodium and potassium. Trace metals were analysed by flame atomic absorption spectrometer (Perkin 3110). The open reflux titrimetric method and Winkler's azide modification methods were used for chemical oxygen demand (COD) and dissolved oxygen (DO), respectively. Biochemical oxygen demand (BOD) was also determined using Winkler's azide modification method. The bottles with the water samples were incubated at $20{ }^{\circ} \mathrm{C}$ for 5 days. The difference between the dissolved oxygen obtained for day 1 and that on day 5 constitute BOD.

\section{Sampling and Preparation for Fish Sample}

Fish samples freshly brought to the shore of the lagoon were obtained from the fishermen. They were put into labelled polyethylene bags. The samples were transferred into a thermoinsulated box, kept on ice, transported to the laboratory and stored in a deep freezer at a temperature of $4^{\circ} \mathrm{C}$. Fish and water sample collection was done weekly between the periods of December 2008 to January 2009.

Fish samples were washed several times with de-ionized water to clean them from sand and other entangled materials. The fish samples were cut into pieces with stainless steel knife into petri-dishes and kept in a deep freezer for about $48 \mathrm{~h}$. The samples were then removed and freeze-dried using the freeze dryer (Christ freeze dryer) for $72 \mathrm{~h}$. They were then ground and homogenized using a blender. Fish samples each weighing $200 \mathrm{mg}$ was packaged into a polyethylene foil and wrapped with an ultra-clean polyethylene foil.

\section{Sample Irradiation Counting and Analysis}

Prepared samples and standards were irradiated using Ghana Research Reactor -1 (GHARR-1) facility at the Ghana Atomic Energy Commission. The reactor was operated at a half power 
of $15 \mathrm{~kW}$ and at a thermal neutron flux of $5 \times 10^{11} \mathrm{ncm}^{-2} \mathrm{~s}^{-1}$. The capsules were sent into the inner irradiation sites of the reactor by means of a pneumatic transfer system operating at a pressure of $0.25 \mathrm{~atm}$. The irradiation time, decay time and counting time were chosen according to the half-life of element of interest. Irradiation times were $2 \mathrm{~min}, 1 \mathrm{~h}$ and $6 \mathrm{~h}$ with corresponding cooling times of $1 \mathrm{~min}, 24 \mathrm{~h}$ and 30 days respectively prior to counting. Samples and standards were irradiated and counted under same conditions. Counting of irradiated samples and standards were done using a PC-based gamma-ray spectroscopy system. Accuracy and precision of the analytical techniques were assessed by the simultaneous activation of certified standard reference materials NIST-SRM 1566 Oyster tissue and NIST SRM 1547 Peach leaves.

\section{RESULTS AND DISCUSSION Hydrochemistry}

The study shows that the electrical conductivity of the lagoon varied between $54.8 \mathrm{mS} / \mathrm{cm}$ and $114.6 \mathrm{mS} / \mathrm{cm}$ with mean value of $87 \pm 19.14$. The $\mathrm{pH}$ values varied between 1.42 and 7.87 with mean value of $6.32 \pm 2.20$. The highest $\mathrm{pH}$ of 7.87 was mainly due to the proximity and influence of the open ocean which normally has a pH range of 7.7 to 8.1 (WRC, 2003). In a lake or pond, the water $\mathrm{pH}$ is affected by its age and the chemical discharge by communities and industries (WRC, 2003). They become acidic with time due to the built up of organic material. As organic substances decay, carbon dioxide forms and combines with water to produce a weak acid called carbonic acid. Large amount of carbonic acid lowers the $\mathrm{pH}$. This was clearly demonstrated at sampling point S7.

Results from the study indicate high level of total dissolved solids (TDS), with mean value of $38.43 \pm 8.43 \mathrm{mg} / \mathrm{l}$. The values exceed the recommended level of $0.5 \mathrm{~g} / \mathrm{l}$ (US EPA, 2012) for aquatic life. Therefore aquatic life may suffer under these conditions

A high value for TDS was recorded for sampling points $\mathrm{S} 1$ and $\mathrm{S} 6$ resulting in an increase in turbidity at these points.

Sampling points S4 and S6 recorded the highest values of $45.4 \mathrm{~g} / \mathrm{l}$ and $50 \mathrm{~g} / \mathrm{l}$ respectively. These sites were located in highly populated residential areas. Effluents from domestic, municipal and small scale industry are suggested to have contributed to the enhanced TDS levels. The electrical conductivity (EC) of the water gradually increased up stream and then declined downstream. Two exceptions were reported for S3 and S6. Their conductivities vary between $74.6 \mathrm{mS} / \mathrm{cm}$ and $114.6 \mathrm{mS} / \mathrm{cm}$. The conductivities of most fresh waters range from 10 to 1000 $\mu \mathrm{S} / \mathrm{cm}$ (Chapman, 1992.). Alkalinity values ranged between $400 \mathrm{mg} / \mathrm{l}$ and $2000 \mathrm{mg} / \mathrm{l}$ with mean value of $1057.14 \pm 499.52$. High $\mathrm{HCO}_{3}{ }^{-}$ alkalinity can only exist in the presence of $\mathrm{Na}^{+}$ dominance.

Alkalinity is important for fish and aquatic life because it protects or buffers against $\mathrm{pH}$ changes and makes water less vulnerable to acid rains. Water plants need light for photosynthesis. If suspended particles and dissolved solids block out light, photosynthesis and the production of oxygen for aquatic life would be reduced.

All seven locations measured nitrate levels above the limit of $10 \mathrm{mg} / 1$ recommended by WHO (WRC, 2003).

Nitrite causes a serious illness (brown blood disease) in fish, even though they do not exist for long in the environment (WRC, 2003). More intensive agricultural production, poor drainage, the spreading of animal manure, sewage sludge effluent all contributed to nitrate leaching. The concentrations of phosphate were very high. The natural background level of $\mathrm{PO}_{4}{ }^{3-}-\mathrm{P}$ in waters usually ranges from 0.005 - $10 \mathrm{mg} / \mathrm{l}$ (WRC, 2003). High phosphorus availability is generally believed to be a critical factor in eutrophication. The recommended limit for sulphate $\left(\mathrm{SO}_{4}{ }^{2-}\right)$ ion is $250 \mathrm{mg} / \mathrm{l}$ for standing and drinking water (US EPA, 2011). The sulphate concentration of the lagoon 
Assessment of water quality parameters...

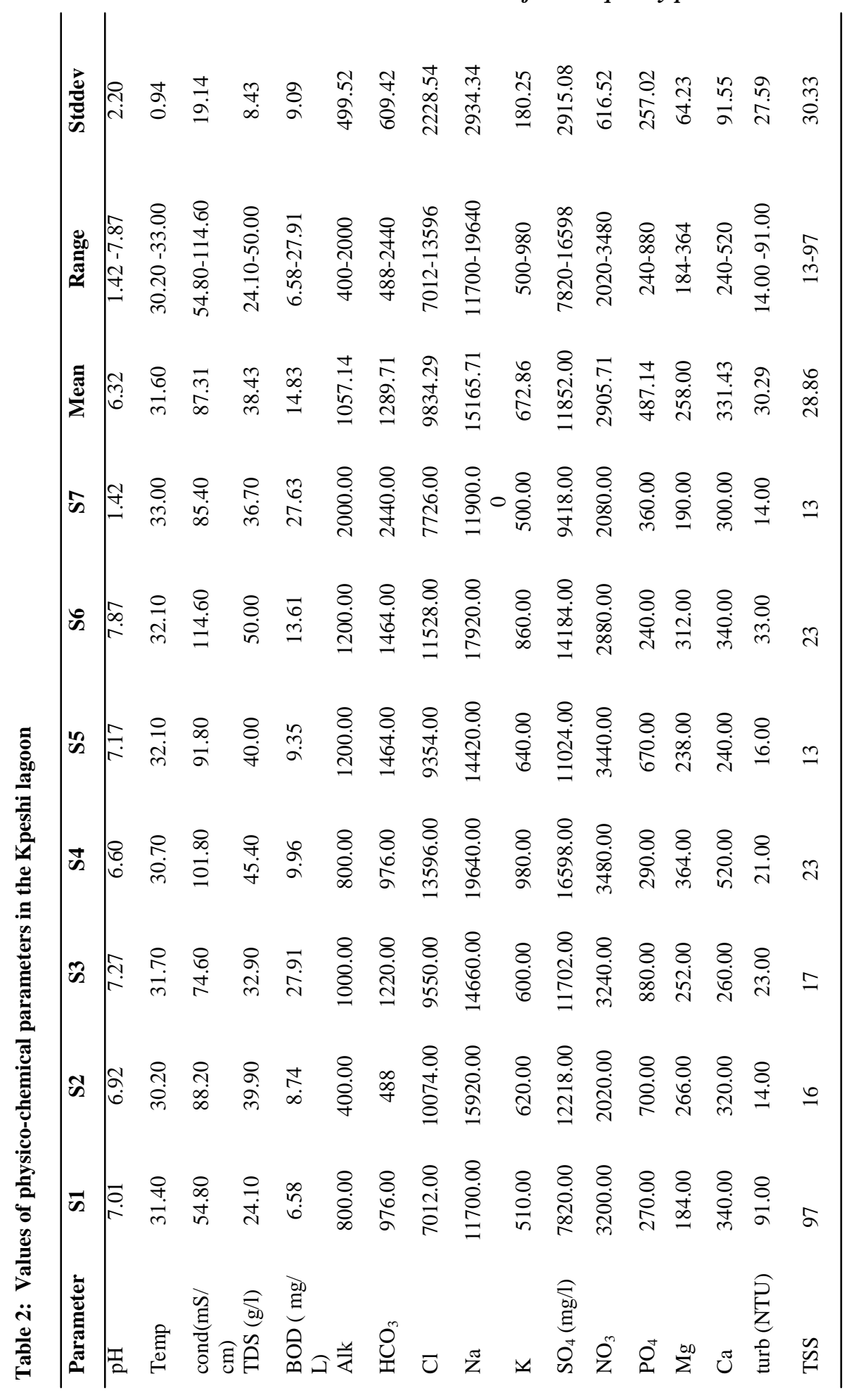

Journal of Science and Technology @ KNUST April 2012 
ranged from 7820 to $16598 \mathrm{mg} / \mathrm{l}$ with $\mathrm{S} 1$ and S4 having the lowest and highest values respectively.

All seven sampling points recorded high BOD values ranging from $6.5 \mathrm{mg} / \mathrm{l}$ to $27 \mathrm{mg} / \mathrm{l}$ with mean value of $14.83 \pm 9.09 \mathrm{mg} / \mathrm{l}$. This was suggested to be as a result of high input of organic matter from domestic and municipal waste which consumed the oxygen in the water as it decayed. Micro organism present in these waste consume dissolved oxygen in the water, making it oxygen deficient thereby threatening aquatic life. water (Karikari et al., 2004).

Table 3 shows the concentration of metals in the lagoon with iron having the highest in all the sampling sites.

Table 4 presents the concentration of trace metals in edible muscle of fish caught with cast net from the southern zone of the lagoon. All the metals were above the maximum permissible limits (UK MAFF (Ministry of Agriculture Fisheries and Food), 1998) for fish. Fish from the Kpeshi lagoon are therefore not safe for human consumption with respect to the metals analysed.

Table 3: Values of heavy metal concentration in the lagoon (mg/l)

\begin{tabular}{lllllllllll}
\hline & S1 & S2 & S3 & S4 & S5 & S6 & S7 & Mean & Range & Stddev \\
\hline $\mathrm{Fe}$ & 8.40 & 7.20 & 13.20 & 6.00 & 12.00 & 3.00 & 8.20 & 8.29 & $3.00-13.20$ & 3.47 \\
$\mathrm{Mn}$ & 0.60 & 0.43 & 0.47 & 0.41 & 0.45 & 1.20 & 1.28 & 0.69 & $0.41-1.28$ & 0.38 \\
$\mathrm{~Pb}$ & 11.60 & 8.60 & 6.00 & 2.00 & 2.60 & 1.80 & 2.10 & 4.96 & $1.80-11.60$ & 3.89 \\
$\mathrm{Cr}$ & 1.60 & 1.40 & 1.80 & 0.20 & 1.00 & 3.00 & 4.00 & 1.86 & $0.20-4.00$ & 1.27 \\
$\mathrm{Ni}$ & 2.80 & 9.20 & 6.00 & 4.00 & 4.20 & 4.00 & 2.80 & 4.71 & $2.80-9.20$ & 2.25 \\
$\mathrm{Cd}$ & 0.40 & 0.42 & 0.41 & 0.45 & 1.00 & 1.40 & 0.80 & 0.70 & $0.40-1.40$ & 0.39 \\
$\mathrm{Al}$ & 6.00 & 12.00 & 9.40 & 13.60 & 5.60 & 4.20 & 1.80 & 7.51 & $1.80-13.60$ & 4.29 \\
\hline
\end{tabular}

Studies carried out in 1968 (EPA, IAB, 1968) on the same lagoon revealed a BOD load of $2.78 \mathrm{mg} / \mathrm{l}$, indicating the intense human activities that have taken place over the last 40 years. Maximum tolerated BOD value should not be more than $20 \mathrm{mg} / \mathrm{l}$ (WRC, 2003).

Chloride concentrations for all seven sampling points were considerably high with mean value of $9834.29 \pm 2228.54 \mathrm{mg} / \mathrm{l}$. However, maximum level for fresh water aquatic life is $230 \mathrm{mg} / \mathrm{l}$ (US EPA, 1988); higher concentration has no adverse effect.

The Kpeshi Lagoon varied considerably in terms of its chemical and physical parameters. Organic matter was the most frequent cause of water quality problem. From Table 2, the ionic dominance of the lagoon was $\mathrm{Na}>\mathrm{K}>\mathrm{Ca}>\mathrm{Mg}$ and $\mathrm{SO}_{4}>\mathrm{CI}>\mathrm{NO}_{3}>\mathrm{HCO}_{3}>\mathrm{PO}_{4}$. This did not agree with ionic patterns for most tropical fresh
Table 4: Metals in fish samples

\begin{tabular}{ll}
\hline Element & Concentration $(\mathbf{m g} / \mathbf{k g})$ \\
\hline $\mathrm{Ca}$ & $15709.91 \pm 75.35$ \\
$\mathrm{Al}$ & $708.47 \pm 4.95$ \\
$\mathrm{Mg}$ & $5171 \pm 92.07$ \\
$\mathrm{Mn}$ & $39.28 \pm 5.43$ \\
$\mathrm{~V}$ & $3.34 \pm 0.05$ \\
$\mathrm{~K}$ & $5999.94 \pm 87.30$ \\
$\mathrm{Na}$ & $3775.70 \pm 24.80$ \\
\hline
\end{tabular}

\section{CONCLUSION}

The results of the study that characterized the Kpeshi lagoon in terms of the physico-chemical properties revealed severe pollution of the lagoon especially with respect to organic matter. The highly polluted sites were those located close to the urbanized, agricultural and industrialized areas. Pollution of this proportion can destroy the aquatic ecosystem of the exposed 
sections of the lagoon. The relatively high concentration of nitrate and phosphate as well as the alkaline nature of the lagoon indicated that it was quite eutrophic.

\section{ACKNOWLEDGEMENT}

The authors thank Meteorological Department at Kotoka International Airport, Accra and Ghana Atomic Energy Commission for the facilities provided. The authors express their utmost gratitude to Mr David Dotse Wemegah of KNUST for his contribution during the map work.

The authors also express gratitude to Messers Osei Akoto, Godfred Darko and Nathaniel Owusu Boadi all at KNUST for proofing the manuscript and making constructive suggestions.

\section{REFERENCES}

Ansah-Asare, D. O and Asante, K. A. (1998). A comparative study of the nutrient status of two reservoirs in southeast Ghana. Lakes and reservoirs: Research and Management, 3: 205-217.

Ansah-Asare, D. O. (2001). Land-based sources of pollution and environmental quality of Weija Lake. J. Gh. Sci. Assoc. 3, 100108. Calvet, R. (Ed), (1990), NitratesAgriculture-Water: International Symposium by INRA, Paris.

Chapman, D. (1992). Water quality assessment, a guide to the use of biota, sediments and water in environmental monitoring. Uni. Press. Cambridge.

Dapaah, S. and Agyekum, W.A. (2002). Hydraulic properties of a fractured granitic aquifer in Central Ghana. J. Gh. Sci. Assoc, 4: 63-64.

Dickson, K. B. and G. Benneh (1980). A new geography of Ghana, Longman, London.

Dugan P. J. (ed.) (1990). Wetland conserva- tion- A review of current issues and required action. IUCN, Gland, Switzerland.

EPA (1983). EPA methods of chemical analysis of water and wastewater. EPA/600/479/020. USA, 374.3.1-375.4.3.

Gray, S., Hanrahan, G., Mckelvie, I., Tappin, A., Tse, F. and Worsfold, P. (2006). Flow analysis techniques for spatial and temporal measurement of nutrients in aquatic systems. Environ. Chem. 3: 4-12.

Karikari, A. Y. and Bosque-Hamilton, E. K. (2004). The water quality of Lake Bosomtwi and its feeder streams. J. Gh. Sci. Assoc. Vol.4 (1): 117-120.

Kjerfve, B. (1986). Comparative Oceanography of Coastal Lagoons. In: D. A Wolfe (org.). Estuarine Variability. Academic Press Columbia, 63-81.

Koukal, B., Dominik, J., Vignati, D., Arpagaus, P., Santiago, S. and Benaabidate, L. (2004). Assessment of water quality and toxicity of polluted Rivers Fez and Sebou in region of Fez (Morocco). Environmental Pollution, 131, 163-170.

Sherman, A. and Sherman S. J. Chemistry And Our Changing World $2^{\text {nd }}$ Edition, Prentice Hall Englewood Cliffs, New Jersey, 1989 and 1983.

Standard Methods (1998). Standard method for the examination of water and wastewater. $20^{\text {th }}$ Ed. American Public Health Association, Washington DC.

US EPA. Water Resource Center (2012). http:// water.epa.gov/aboutow/ownews/wrc/x.cfm (Accessed on 06/03/2012)

US EPA (2011). Inorganic Contaminants and Other constituents. (PDF) (Accessed on 06/03/2012) http://www.epa.gov/safewater/ sulpfate.html 


\section{Apau et al.}

US EPA (1988). Ambient water quality criteria for chloride. Office of water, Washington, DC.

UK MAFF (1998). Concentrations of metals and other elements in marine fish and shell- fish. Number 151.

WRC (2003). Groundwater Assessment: An Element of Integrated Water Resources Management - the case of Densu River Basin. WRC. Accra. 